\title{
ANALIZA TURYSTYKI UZDROWISKOWEJ NA PRZYKŁADZIE KOŁOBRZEGU
}

\author{
Natalia Oleszczyka (iD, Natalia Dominiak ${ }^{\mathrm{b}}$ \\ ${ }^{a}$ Zachodniopomorski Uniwersytet Technologiczny w Szczecinie, Wydział Ekonomiczny, Katedra Studiów Regionalnych \\ i Europejskich; https://orcid.org/0000-0002-8441-8054; e-mail: Natalia.Oleszczyk@zut.edu.pl \\ ${ }^{\mathrm{b}}$ Zachodniopomorski Uniwersytet Technologiczny w Szczecinie, Wydział Ekonomiczny, Katedra Studiów Regionalnych \\ i Europejskich; https://orcid.org/0000-0002-8287-6350; e-mail: Natalia.Dominiak@zut.edu.pl
}

\begin{abstract}
ABSTRAKT
Na przestrzeni ostatnich lat odnotowuje się rosnące zainteresowanie turystyką uzdrowiskową na świecie, a także znaczny wzrost świadomości społecznej w kwestii dbałości o zdrowie, kondycję fizyczną i dobre samopoczucie. Poza turystyką uzdrowiskową dużym zainteresowaniem cieszy się także turystyka spa \& wellness. Kołobrzeg oprócz tego, że jest miejscowością nastawioną w dużej mierze na kuracjuszy, przyciąga również turystów korzystających z zabiegów spa \& wellness. Celem artykułu jest wyjaśnienie istoty i dokonanie charakterystyki turystyki uzdrowiskowej na przykładzie Kołobrzegu. Działalność uzdrowiskowa prowadzona jest w podmiotach leczniczych, znajdujących się na obszarze uzdrowiska. Są to obiekty, w których kuracjusze przebywają na leczeniu lub odbywają rehabilitację. Podmioty te korzystają z leczniczych warunków naturalnych obszarów, na których działają i ich mikroklimatu. W głównej części artykułu zaprezentowano historię turystyki uzdrowiskowej w Kołobrzegu oraz analizę oferty uzdrowisk i ich profilu leczniczego. Ponadto w części empirycznej omówiono wyniki przeprowadzonej wśród kuracjuszy analizy orientacyjnej z wykorzystaniem metody badań ankietowych, z których znaczną część respondentów stanowiły osoby po 65 roku życia, głównie kobiety. Respondenci w trakcie badania, ocenili różne aspekty pobytu uzdrowiskowego (w skali od 1 do 5), na poziomie powyżej 4,0, co wskazuje na dobre warunki i ogólne zadowolenie kuracjuszy z przebywania w mieście.
\end{abstract}

\section{SŁOWA KLUCZOWE}

uzdrowisko, turystyka uzdrowiskowa, Kołobrzeg

\section{INFORMACJE O ARTYKULE}

Przyjęto:

27 kwietnia $2020 \mathrm{r}$.

Zaakceptowano:

11 maja $2021 \mathrm{r}$.

Opublikowano:

25 czerwca $2021 \mathrm{r}$

\section{WSTĘP}

Turystyka uzdrowiskowa wraz z turystyką leczniczą (medyczną) oraz spa \& wellness zaliczana jest do form turystyki zdrowotnej. Według Wolskiego (1970, s. 11) rozumiana jest jako „świadome i dobrowolne udanie się na pewien okres poza miejsce zamieszkania, w czasie wolnym od pracy, w celu regeneracji ustroju dzięki aktywnemu wypoczynkowi fizycznemu i psychicznemu". Podobnie turystykę uzdrowiskową definiują Gaworecki (2003) oraz Kornak i Rapacz (2001), określając ją jako działalność realizowaną w miejscowościach uzdrowiskowych, związaną z lecznictwem (m.in. rehabilitacja, profilaktyka, leczenie). W swoich rozważaniach określają uzdrowisko jako wydzielony obszar, na którym prowadzona jest działalność o charakterze uzdrowiskowym (Gaworecki, 2003; Kornak, Rapacz, 2001).

Obecnie w Polsce mamy do czynienia ze społeczeństwem starzejącym się (Adamczyk, 2017). Wydłuża się średnia długość życia (w 2019 r. średnia długość trwania życia kobiet wyniosła 81,8 roku, a mężczyzn - 74,1 roku, jest to wzrost w stosunku do 2018 r. - odpowiednio dla kobiet o 0,1 roku i dla mężczyzn o 0,3 roku (GUS, 
2020). Stąd też turystyka uzdrowiskowa uznawana jest za produkt, który cieszy się dużym zainteresowaniem klientów krajowych. Występujące w Polsce bogactwa naturalne o właściwościach leczniczych, jak np.: źródła wód mineralnych, złoża borowin, mikroklimat, dzięki efektywnemu wykorzystaniu, stanowią jeden z czynników rosnącej konkurencyjności kraju na arenie międzynarodowej.

Wśród głównych czynników wpływających na rozwój turystyki uzdrowiskowej, poza wspomnianymi wcześniej, należy wymienić:

- modę na prowadzenie zdrowego stylu życia;

- rosnące oczekiwania kuracjuszy i turystów niebędących kuracjuszami;

- dużą popularność uzdrowisk, które mają bogatą historię;

- możliwość skrócenia czasu potrzebnego na powrót do sprawności i zdrowia, w wyniku korzystania z oferowanych zabiegów oraz częstotliwości ich wykonywania;

- widoczne zróżnicowanie oferty turystycznej pod względem jakości świadczonych usług i ceny (Januszewska, 2004).

Należy też zwrócić uwagę na fakt, że coraz częściej ludzie poszukują miejsc w pobliżu środowiska naturalnego, w których nie nastąpiła zbyt duża ingerencja człowieka. Obiekty turystyki uzdrowiskowej często są zlokalizowane w pobliżu lasów, parków, parków narodowych, parków krajobrazowych, rezerwatów przyrody.

Status uzdrowiska lub obszaru ochrony uzdrowiskowej może zostać przyznany jedynie strefie, która spełnia ściśle określone warunki wynikające z Ustawy z dnia 28 lipca 2005 r. o lecznictwie uzdrowiskowym, uzdrowiskach i obszarach ochrony uzdrowiskowej oraz o gminach uzdrowiskowych (Ustawa, 2016), m.in.:

- znajdują się w niej złoża surowców naturalnych i panuje tam klimat o właściwościach leczniczych, co zostało potwierdzone odpowiednimi badaniami;

- spełnia wszelkie wymogi, które zostały ściśle określone w przepisach dotyczących ochrony środowiska;

- utrzymywana jest tam sprawna infrastruktura techniczna, głównie w zakresie gospodarki wodno-ściekowej i energetycznej oraz zarządzania odpadami, a także transportu zbiorowego;

- znajdują się tam obiekty i odpowiednie urządzenia lecznictwa uzdrowiskowego, wyspecjalizowane w zakresie przeprowadzania kuracji leczniczych (Bernat, Harasimiuk, 2019; Makała, 2016).

W sytuacji gdy spełnione są trzy pierwsze z wymienionych kryteriów, a czwarte nie, władze gminy mogą starać się o uzyskanie dla niej statusu obszaru ochrony uzdrowiskowej.

Na terenie całego kraju zlokalizowanych jest 45 miejscowości uzdrowiskowych (Uzdrowiska, 2020; Wykaz uzdrowisk, 2020). Turystyka uzdrowiskowa w Polsce uprawiana jest na obszarach ochrony uzdrowiskowej oraz gmin uzdrowiskowych, gdzie poza prowadzeniem działalności o charakterze leczniczym, uzdrowiskowym i zdrowotnym świadczone są również usługi turystyczne. W pasie nadmorskim i pojeziernym województwa zachodniopomorskiego są to m.in.: Świnoujście, Kamień Pomorski, Dąbki, Kołobrzeg, Połczyn-Zdrój. Największą popularnością wśród uzdrowisk w Polsce północnej cieszy się Kołobrzeg.

\section{ISTOTA I FUNKCJE UZDROWISK}

Najwcześniejsze wzmianki o lecznictwie uzdrowiskowym pojawiły się w V w. p.n.e. Pierwszym medykiem, który zainteresował się wykorzystaniem bogactw naturalnych w leczeniu organizmu człowieka, był Hipokrates (Trzeciak, 1997). Jednak wyjazdy do uzdrowisk były formą wypoczynku od najdawniejszych czasów. Tereny, na których znajdowały się ciepłe źródła, stały się celem wyjazdów rzymskich możnowładców, spędzających tam miło czas. Rzymianie byli prekursorami w dziedzinie kąpielisk. Upodobania do kąpieli przejęli później muzułmanie, głównie Arabowie i Turcy. To właśnie Turcy stworzyli typ łaźni znany do dziś pod nazwą łaźnia turecka (Małecka, Marcinkowski, 2007).

Podróże do wód na dużą skalę rozwinęły się jednak dopiero w XVIII w. Pobyty w uzdrowiskach, często o starożytnych korzeniach, stały się modne wśród elity społeczeństw całej Europy. Szczyt popularności uzdrowisk przypada na kolejne stulecie. Wówczas, wraz z budową linii kolejowych w XIX w., poprawiła się ich dostępność komunikacyjna i ekonomiczna. Uzdrowiska stały się ulubionym miejscem kuracji i wypoczynku przedstawicieli wolnych zawodów: pisarzy, malarzy, śpiewaków, aktorów. W XX w. następowała dalsza demokratyzacja produktu uzdrowiskowego - wśród klientów sanatoriów pojawili się reprezentanci wszystkich warstw społecznych (Kaczmarek, Stasiak, Włodarczyk, 2010).

Obecnie w literaturze przedmiotu uzdrowiska traktowane są jako atrakcje turystyczne (Kruczek, 2012). Za takowe uznaje się wszelkie elementy wchodzące w skład produktu turystycznego, które są określone jako szczególne ze względu na zdolność przyciągania turystów i kluczowe znaczenie w podejmowaniu decyzji o wyborze miejsca wypoczynku. Wraz z usługami turystycznymi tworzą one gotowy produkt turystyczny (Kruczek, 2011). Dotychczas stosunkowo rzadko były podejmowane próby zbadania atrakcyjności uzdrowisk w Polsce. Według Szromka (2013), dokonując analizy atrakcyjności obszaru, należy skoncentrować się na badaniach nad warunkującymi ją walorami (przede wszystkim mowa tu o atrakcjach turystycznych).

Polskie uzdrowiska funkcjonują na podstawie Ustawy z dnia 28 lipca 2005 r. o lecznictwie uzdrowiskowym, 
uzdrowiskach i obszarach ochrony uzdrowiskowej oraz o gminach uzdrowiskowych (Ustawa, 2016). W dokumencie tym termin „uzdrowisko" został zdefiniowany jako „obszar, na terenie którego prowadzone jest lecznictwo uzdrowiskowe, wydzielony w celu wykorzystania i ochrony znajdujących się na jego obszarze naturalnych surowców leczniczych".

Polski Komitet Normalizacyjny określa uzdrowisko jako obszar charakteryzujący się złożami naturalnych surowców, dostępem do wód morskich i klimatem wykazującym właściwości lecznicze (wystarczy, aby spełniony był chociaż jeden z tych trzech czynników) oraz taki, na którym znajdują się urządzenia i zakłady umożliwiające lecznictwo uzdrowiskowe (Burzyński, 2005).

Obiekty uzdrowiskowe zlokalizowane są w każdej strefie krajobrazowej w Polsce, jednak najwięcej występuje ich w pasie górskim i nadmorskim. Dzięki bezpośredniemu dostępowi do walorów przyrodniczych, krajobrazowych i geograficznych możliwe jest połączenie pobytów leczniczych z turystycznymi, co stanowi szansę rozwoju turystyki uzdrowiskowej (Gotowt-Jeziorska, Wyrzykowski, 2005).

Według Gaworeckiego (2003) istnieją trzy główne motywy uprawiania turystyki: chęć poznawania świata (motywy poznawcze); chęć odnowy sił fizycznych i psychicznych, w tym poprawy stanu zdrowia i samopoczucia (motywy wypoczynkowe); potrzeba aktywnego wypoczynku (motywy specjalistyczne). Wskazane przez tego badacza determinanty uprawiania turystyki mają zastosowanie zarówno w przypadku turystyki zdrowotnej, jak i np. aktywnej.

\section{TURYSTYKA UZDROWISKOWA W KOŁOBRZEGU}

W XIX w. Kołobrzeg należał do państwa pruskiego i nosił niemiecką nazwę Kolberg. Historia powstania uzdrowiska w tym mieście jest trochę nietypowa. W $1802 \mathrm{r}$. H.H. von Held, pełniący funkcję radcy celnego w Poznaniu, odbywał karę aresztu w kołobrzeskiej twierdzy. Po wydaniu książki, w której opisał, że swoje zdrowie zawdzięcza falom Bałtyku, miejscowość zaczęło odwiedzać coraz więcej osób, jednak utrudnieniem w utworzeniu kapielisk był status twierdzy (Cieślukowski, 1975).

W 1830 r. G. Keutel założył pierwszy zakład kąpieli solankowych. Jednak to dr M. Behrend został okrzyknięty ojcem lecznictwa uzdrowiskowego w Kołobrzegu (Heider, Kierzek, Laber, Kotuła, 2019). M. Behrend, po odkupieniu sprzętów od G. Keutla, rozpoczął profesjonalne leczenie ludzi. Następnie zaczęły powstawać zakłady kąpieli solankowych i ciepłych kąpieli morskich. Wprowadzono picie zarówno solanek, jak też owczej serwatki. Dopiero po utraceniu statusu twierdzy, tj. po 1872 r., Kołobrzeg przekształcono w kurort (Historia uzdrowiska, 2020).
W 1899 r. do użytku został oddany pierwszy dom zdrojowy - Pałac Nabrzeżny. Było to sanatorium zbudowane w stylu niemieckiego renesansu. W 1911 r. podczas międzynarodowego kongresu do spraw lecznictwa przyznano Kołobrzegowi rangę uzdrowiska pierwszej kategorii (Heider, Kierzek, Laber, Kotuła, 2019). Kolejny okres świetności tego kurortu przypadł na lata międzywojenne. Kołobrzeg zyskał wówczas miano Perły Bałtyku i palmę pierwszeństwa wśród 125 niemieckich uzdrowisk. W 1939 r. liczba kuracjuszy w Kołobrzegu wyniosła 46 tys. Po II wojnie światowej miasto znalazło się w granicach Polski, jednak w wyniku oblężenia w 1945 r. zostało zniszczone w 90\%.

Odbudowa Kołobrzegu i jego dzielnicy uzdrowiskowej rozpoczęła się na początku lat 50 . XX w. Systematyczną działalność uzdrowiskową w kołobrzeskich ośrodkach wznowiono dopiero w 1952 r. Status uzdrowiska miasto otrzymało w 1967 r. (Urząd Miasta Kołobrzeg, 2020).

Lata 80. minionego stulecia upłynęły pod znakiem wielkiego kryzysu gospodarczego i inwestycyjnego w centralnie sterowanej gospodarce Polski. Wstrzymano wszelkie inwestycje turystyczne i uzdrowiskowe oraz remonty. W 1989 r. rozpoczął się okres wielkich przemian ustrojowych w Polsce. Miasto Kołobrzeg oraz działające na jego terenie obiekty turystyczne musiały dostosować się do wymogów kapitalistycznej gospodarki wolnorynkowej. Zmiany, które dokonały się w Kołobrzegu pod względem struktury, form własności oraz zróżnicowania i funkcjonowania turystycznych obiektów, można określić mianem rewolucyjnych i przełomowych (Miedziński, 2011). Przystąpienie Polski do Unii Europejskiej w 2004 r. zbiegło się w czasie z komercjalizacją spółek uzdrowiskowych oraz wprowadzeniem nowej ustawy uzdrowiskowej. To okres możliwości pozyskiwania dotacji unijnych przez lokalne samorządy i spółki uzdrowiskowe i korzystania z nich. W tym czasie poczyniono wielkie postępy w zakresie marketingu, promocji uzdrowisk, poprawy infrastruktury technicznej, głównie sanitarnej, oraz podniesienia jakości przestrzeni publicznych (Wójcikowski, 2015).

Kołobrzeg po 20 latach przemian ustrojowych i rozwoju gospodarki wolnorynkowej jest obecnie największym, najnowocześniejszym ośrodkiem turystyki uzdrowiskowo-wypoczynkowej w Polsce (Miedziński, 2011). Pobyty w uzdrowisku wiążą się z leczeniem chorób układu nerwowego, oddechowego, skóry oraz z zakresu ortopedii, kardiologii, reumatologii, endokrynologii, cukrzycy, otyłości i osteoporozy, a także urazów (Kołobrzeg, 2020).

Spośród miejscowości uzdrowiskowych w Polsce Kołobrzeg wyróżniają duże złoża solanek i borowin, a także klimat (Gillert, 1964). Na terenie tego najpopularniejszego uzdrowiska w pasie nadmorskim znajdują się wody lecznicze, wykorzystywane m.in. przy 
kuracjach stosowanych w przypadku reumatyzmu, rwy kulszowej, stanów zapalnych stawów, mięśni i kości, a także miażdżycy i wielu innych schorzeń. Zabiegi borowinowe są wielkim atutem z punktu widzenia turystyki uzdrowiskowej miasta. Ponadto do walorów przyrodniczych można zaliczyć niewątpliwie mikroklimat obszaru nadmorskiego, piękną nadmorską przyrodę oraz roślinność. Przez miasto przepływa rzeka Parsęta, w której wodach żyje 27 gatunków ryb (Kroczyński, 1969). Dolina Parsęty ze względu na swój charakter ekologiczny zaliczana jest do obszarów programu „Natura 2000” (Przyroda Kołobrzegu i okolic, 2020). Do najważniejszych walorów antropogenicznych Kołobrzegu należy zaliczyć m.in.: molo, latarnię morska, bazylikę Wniebowzięcia NMP, Muzeum Oręża Polskiego, Muzeum Bursztynu, Basztę Lontową i Pomnik Zaślubin Polski z Morzem (Atrakcje w Kołobrzegu, 2020).
Zabiegi lecznicze prowadzone są przez placówki o różnym charakterze. W tabeli 1 zestawiono obiekty noclegowe, w których świadczone są usługi uzdrowiskowo-lecznicze w Kołobrzegu, wraz z ich profilami leczniczymi. W znacznej części obiektów w Kołobrzegu prowadzone jest leczenie uzdrowiskowe w szerokim zakresie. Ciekawym przykładem jest Magnolia SPA, w której oferowany jest jedynie pobyt rehabilitacyjny z możliwością dofinansowania PFRON oraz tygodniowy pobyt leczniczy, obejmujący zabiegi rehabilitacyjne.

Podczas pobytu w wymienionych $\mathrm{w}$ tab. 1 obiektach, goście korzystają z szerokiej bazy zabiegowej. Kuracjusze mają też do dyspozycji wiele dodatkowych urządzeń rekreacyjno-wypoczynkowych, do których zalicza się m.in. baseny, sauny, groty solno-jodowe, seanse jodowe, ścieżki nordic walking.

Tabela 1. Profil lecznictwa obiektów leczniczo-uzdrowiskowych w Kołobrzegu

\begin{tabular}{|c|c|c|c|c|c|c|c|c|c|c|c|c|c|c|}
\hline Lp. & 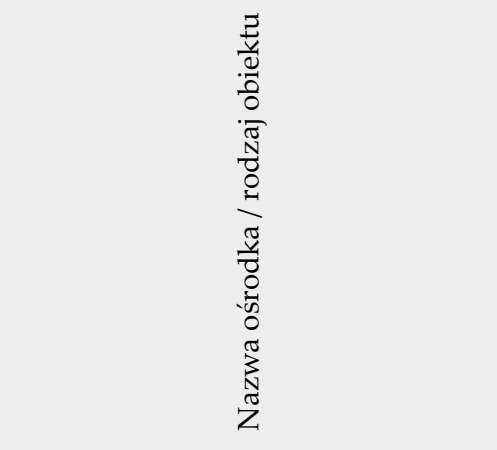 & 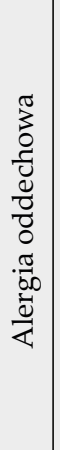 & 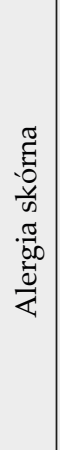 & 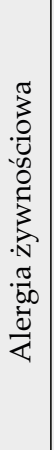 & 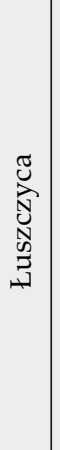 & 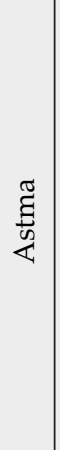 & 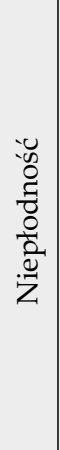 & 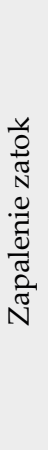 & 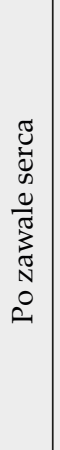 & 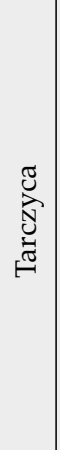 & 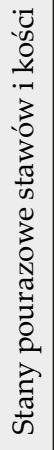 & 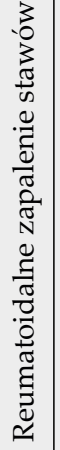 & $\begin{array}{l}\frac{0}{0} \\
0 \\
0 \\
0 \\
3 \\
0 \\
2\end{array}$ & $\underset{\Xi}{\Xi}$ \\
\hline 1. & Arka Medical Spa Hotel ${ }^{* * * *}$ & + & - & - & + & + & + & - & + & - & - & - & - & - \\
\hline 2. & $\begin{array}{l}\text { Centrum Rehabilitacji Rolników } \\
\text { KRUS Niwa }\end{array}$ & - & - & - & + & + & - & + & - & - & + & - & - & przebyty udar mózgu \\
\hline 3. & $\begin{array}{l}\text { Centrum Zdrowia i Wypoczynku } \\
\text { Ikar }\end{array}$ & - & - & - & - & - & - & - & - & - & + & + & - & $\begin{array}{c}\text { migreny, choroby układu } \\
\text { żylnego }\end{array}$ \\
\hline 4. & $\begin{array}{l}\text { Centrum Zdrowia i Relaksu } \\
\text { VERANO }\end{array}$ & - & - & - & - & + & - & + & + & - & + & - & - & $\begin{array}{c}\text { porażenie mózgowe } \\
\text { u dzieci }\end{array}$ \\
\hline 5. & Jantar Hotel \& Spa & - & - & - & - & - & - & + & - & - & - & + & + & $\begin{array}{l}\text { przewlekłe zapalenie } \\
\text { oskrzeli, rehabilitacja } \\
\text { po protezoplastyce }\end{array}$ \\
\hline 6. & Kurhotel Etna & - & - & - & - & - & - & - & - & - & + & + & - & $\begin{array}{l}\text { przewlekłe zapalenie } \\
\text { oskrzeli, migrena, } \\
\text { nadciśnienie tętnicze }\end{array}$ \\
\hline 7. & Magnolia SPA & - & - & - & - & - & - & - & - & - & - & - & - & - \\
\hline 8. & Mona Lisa Boutique Wellness \& Spa & - & - & - & - & + & - & - & - & - & - & + & - & rwa kulszowa, cukrzyca \\
\hline 9. & Olymp II & - & - & - & - & - & - & + & - & - & + & + & + & $\begin{array}{c}\text { przewlekłe zapalenie } \\
\text { oskrzeli }\end{array}$ \\
\hline 10. & $\begin{array}{l}\text { Ośrodek Leczniczo-Wypoczynkowy } \\
\text { Kormoran Sp. z o.o. }\end{array}$ & - & - & + & - & + & - & + & + & - & + & - & - & - \\
\hline 11. & $\begin{array}{l}\text { Ośrodek Phoenix } \\
\text { - Obiekt Sanatoryjno-Wczasowy }\end{array}$ & - & - & - & - & + & - & - & - & - & + & - & - & $\begin{array}{l}\text { migrena, } \\
\text { zespoły korzonkowe }\end{array}$ \\
\hline 12. & $\begin{array}{l}\text { Ośrodek Rehabilitacyjno- } \\
\text {-Sanatoryjny Perełka }\end{array}$ & - & - & - & - & - & - & + & - & + & + & + & + & $\begin{array}{c}\text { nieżyty } \\
\text { dróg oddechowych }\end{array}$ \\
\hline
\end{tabular}




\begin{tabular}{|c|c|c|c|c|c|c|c|c|c|c|c|c|c|c|}
\hline Lp. & 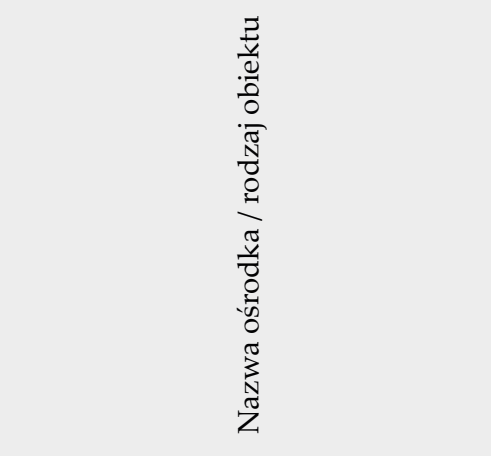 & 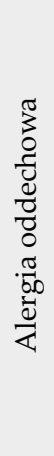 & 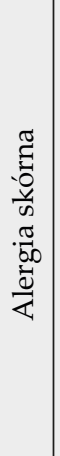 & 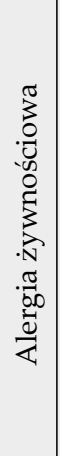 & 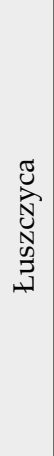 & 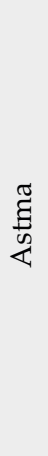 & 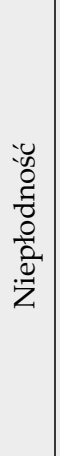 & 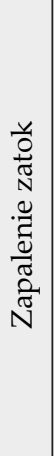 & 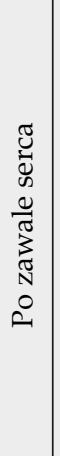 & 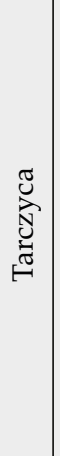 & 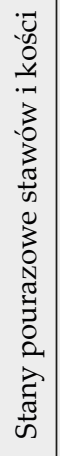 & 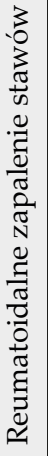 & $\begin{array}{l}\frac{0}{\circ} \\
0 \\
0 \\
3 \\
0 \\
2\end{array}$ & $\underset{\Xi}{\Xi}$ \\
\hline 13. & $\begin{array}{l}\text { Ośrodek Sanatoryjno-Wczasowy } \\
\text { Poznanianka }\end{array}$ & - & + & - & - & - & - & + & - & - & - & - & - & $\begin{array}{l}\text { przewlekłe zapalenie } \\
\text { oskrzeli, rehabilitacja } \\
\text { po protezoplastyce, } \\
\text { zwyrodnienie kręgosłupa }\end{array}$ \\
\hline 14. & $\begin{array}{l}\text { Ośrodek Sanatoryjno- } \\
\text {-Wypoczynkowy Bursztyn }\end{array}$ & - & - & - & - & - & - & + & - & - & + & - & - & $\begin{array}{c}\text { przewlekłe zapalenie } \\
\text { oskrzeli, migrena, otyłość }\end{array}$ \\
\hline 15. & $\begin{array}{l}\text { Ośrodek Sanatoryjno- } \\
\text {-Wypoczynkowy Olymp }\end{array}$ & - & - & - & - & - & - & - & - & - & + & + & - & migrena \\
\hline 16. & $\begin{array}{l}\text { Sanatorium Mewa 1, Pawilon A } \\
\text { - Uzdrowisko Kołobrzeg S.A. }\end{array}$ & + & - & - & + & + & + & - & + & - & - & - & - & - \\
\hline 17. & $\begin{array}{l}\text { Sanatorium Mewa 1, Pawilon B } \\
\text { - Uzdrowisko Kołobrzeg S.A. }\end{array}$ & + & - & - & + & + & - & + & + & - & - & - & - & - \\
\hline 18. & $\begin{array}{l}\text { Sanatorium Mewa } 2 \\
\text { - Uzdrowisko Kołobrzeg S.A. }\end{array}$ & + & - & - & + & + & - & + & + & - & - & - & - & - \\
\hline 19. & $\begin{array}{l}\text { Sanatorium Mewa } 3 \\
\text { - Uzdrowisko Kołobrzeg S.A. }\end{array}$ & + & - & - & + & + & - & + & + & - & - & - & - & - \\
\hline 20. & $\begin{array}{l}\text { Sanatorium Mewa } 4 \\
\text { - Uzdrowisko Kołobrzeg S.A. }\end{array}$ & + & - & - & + & + & + & - & + & - & - & - & - & - \\
\hline 21. & Sanatorium MSW w Kołobrzegu & - & - & - & - & - & - & - & - & - & - & - & - & cukrzyca \\
\hline 22. & $\begin{array}{l}\text { Sanatorium Perła Bałtyku } \\
\text { (Kombatant) }\end{array}$ & - & - & - & - & - & - & - & + & - & + & - & - & $\begin{array}{c}\text { gruźlica, zwyrodnienia } \\
\text { kręgosłupa, rehabilitacja } \\
\text { po mastektomii }\end{array}$ \\
\hline 23. & Sanatorium SAN & - & - & + & - & - & - & - & - & - & - & - & - & - \\
\hline 24. & Sanatorium Uzdrowiskowe Bałtyk & - & - & - & - & - & - & - & - & - & - & + & - & - \\
\hline 25. & $\begin{array}{l}\text { Sanatorium Uzdrowiskowe } \\
\text { Kielczanka-Albax }\end{array}$ & - & - & + & + & + & - & + & - & - & + & - & - & - \\
\hline 26. & $\begin{array}{l}\text { Sanatorium Uzdrowiskowe Koral- } \\
\text {-Live }\end{array}$ & - & - & - & - & + & - & + & - & - & + & - & - & $\begin{array}{c}\text { rwa kulszowa, } \\
\text { nadciśnienie tętnicze }\end{array}$ \\
\hline 27. & Sanatorium Uzdrowiskowe Lech & - & - & - & - & + & - & - & - & + & + & - & + & $\begin{array}{l}\text { przewlekłe nieżyty } \\
\text { układu oddechowego }\end{array}$ \\
\hline 28. & Sanatorium Uzdrowiskowe Mesko & + & - & - & - & + & - & + & - & - & + & - & + & - \\
\hline 29. & $\begin{array}{l}\text { Sanatorium Uzdrowiskowe } \\
\text { Posejdon }\end{array}$ & - & - & - & - & + & - & + & - & - & - & - & - & $\begin{array}{c}\text { rehabilitacja } \\
\text { po mastektomii, } \\
\text { cukrzyca }\end{array}$ \\
\hline 30. & Sanatorium Uzdrowiskowe Wistom & + & - & - & - & + & - & + & - & - & + & - & + & - \\
\hline 31. & $\begin{array}{l}\text { Szpital Uzdrowiskowy Muszelka } \\
\text { - Uzdrowisko Kołobrzeg S.A. }\end{array}$ & + & - & - & - & + & - & + & + & - & + & - & - & - \\
\hline 32. & $\begin{array}{l}\text { Szpital Uzdrowiskowy Słoneczko } \\
\text { - Uzdrowisko Kołobrzeg S.A. }\end{array}$ & + & - & - & - & - & - & - & - & + & - & - & - & $\begin{array}{l}\text { leczenie po operacjach } \\
\text { torakochirurgicznych }\end{array}$ \\
\hline 33. & Willa Fortuna & - & - & + & - & + & - & + & + & - & - & - & - & $\begin{array}{c}\text { rehabilitacja } \\
\text { po protezoplastyce }\end{array}$ \\
\hline
\end{tabular}

Źródło: opracowanie własne na podstawie Sanatoria.org (2020). 
Najwięcej obiektów spośród wymienionych w tab.1 specjalizuje się w leczeniu i rehabilitacji związanymi z astmą (19 obiektów), zapaleniem zatok (18 obiektów) oraz stanami pourazowymi stawów i kości (17 obiektów). Tylko jeden ośrodek zajmuje się leczeniem alergii skórnej.

Należy pamiętać, że lecznictwo uzdrowiskowe stanowi kontynuację leczenia ambulatoryjnego bądź szpitalnego, które ma wspomóc pacjenta, aby odzyskał sprawność po wypadku lub chorobie, wykorzystując do tego naturalne surowce lecznicze oraz właściwości mikroklimatu. W uzdrowisku kuracjusze uczęszczają również na zabiegi fizjoterapeutyczne, a podczas pobytu na leczeniu każdy z uczestników może skorzystać z bezpłatnych badań diagnostycznych oraz leków i wyrobów medycznych, które są niezbędne do przeprowadzenia kuracji (Lecznictwo uzdrowiskowe, 2020).

\section{METODYKA BADAŃ}

Głównym celem badania było określenie, jakie są najczęstsze motywy przyjazdu kuracjuszy do Kołobrzegu (w tym problemy zdrowotne, z powodu których znaleźli się w sanatorium), a także ich oczekiwania względem pobytu w uzdrowisku. W części empirycznej wykorzystano metodę badań ankietowych, które zostały przeprowadzone osobiście przez autorki w Kołobrzegu w 2019 r. Dobór próby do badań był losowy. Wzięło w nich udział 118 osób z Polski, przebywających w uzdrowiskach. Badania te miały charakter eksploracyjny. Respondenci udzielali odpowiedzi na pytania zamknięte, dotyczące m.in. celu przyjazdu do Kołobrzegu, głównych schorzeń, atrakcji turystycznych, z których chcą skorzystać bądź korzystają podczas pobytu. Dzięki ankiecie uzyskano również informacje dotyczące m.in. oceny przez kuracjuszy (np. ceny pobytu czy wyżywienia), a także źródeł finansowania wyjazdów. Wyniki zostały przedstawione $\mathrm{w}$ formie tabelarycznej i na wykresie.

\section{WYNIKI BADAŃ}

W badaniach wzięło udział więcej kobiet (69\%) niż mężczyzn (31\%). Osoby w wieku 55-65 lat oraz powyżej 65 roku życia stanowiły prawie $86 \%$ ankietowanych. Najmniej wśród respondentów było osób poniżej 45 roku życia (6\%) i w wieku 45-55 lat (8\%). Ankietowani odpowiadali najczęściej, że wyjeżdżają do sanatorium co dwa lata ( $28 \%$ ). Ponad $50 \%$ badanych wybiera pobyty 21 -dniowe, jedynie niespełna $8 \%$ - pobyty tygodniowe. Wśród ankietowanych przeważali kuracjusze z wykształceniem wyższym (50,8\%), których dochód miesięczny przekraczał 2000 zł. Zdecydowana większość turystów uzdrowiskowych, którzy przyjechali do Kołobrzegu, mieszkała na co dzień w mieście (66\%). Ponad połowa respondentów była już wcześniej w Kołobrzegu (52,5\%).

Pierwsze pytanie, które umieszczono w ankiecie, dotyczyło głównego motywu wyjazdu (tab. 2). Najczęściej wskazywaną przyczyną była chęć ogólnej poprawy stanu zdrowia oraz potrzeba leczenia schorzeń i polepszenia kondycji fizycznej i psychicznej. Najrzadziej za główny powód uznawano chęć nawiązania nowych znajomości (18\% odpowiedzi, z czego 17,1\% udzieliły kobiety).

Respondentów zapytano także o dolegliwości zdrowotne, które są przyczyną ich przyjazdu do Kołobrzegu. Badani wskazywali najczęściej reumatoidalne zapalenie stawów i kości (36\%), choroby układu oddechowego (30\%) oraz cukrzycę (29\%). Należy zauważyć, że nerwobóle pojawiały się wyłącznie w odpowiedziach udzielanych przez kobiety. Schorzeniem najczęściej wymienianym przez mężczyzn były choroby kardiologiczne, natomiast kobiety wskazywały najczęściej reumatoidalne zapalenie stawów i kości.

Kolejne pytanie dotyczyło zabiegów, w których ankietowani uczestniczyli podczas pobytu w miejscowości nadmorskiej (tab. 3). Z udzielonych odpowiedzi wynika, że kuracjusze najczęściej korzystali z masaży (51\%), kąpieli w basenie solankowym (32\%), kinezyterapii (32\%) oraz inhalacji (31\%), najrzadziej zaś z zabiegów borowinowych (wskazało je 13,9\% mężczyzn i 23,2\% kobiet).

Tabela 2. Główny motyw wyjazdu

\begin{tabular}{|l|c|c|c|c|c|c|}
\hline \multirow{2}{*}{ Główny motyw wyjazdu } & \multicolumn{2}{|c|}{ Ogółem } & \multicolumn{2}{c|}{ Kobiety } & \multicolumn{2}{c|}{ Mężczyźni } \\
\cline { 2 - 7 } & os. & $\%$ & os. & $\%$ & os. & \multicolumn{2}{c|}{$\%$} \\
\hline Poprawa stanu zdrowia & 35 & 30 & 27 & 32,9 & 8 & 22,2 \\
\hline Leczenie schorzeń zgodnie z zaleceniami lekarza & 23 & 19 & 13 & 15,9 & 10 & 27,8 \\
\hline $\begin{array}{l}\text { Ogólna poprawa kondycji fizycznej } \\
\text { i psychicznej }\end{array}$ & 22 & 19 & 16 & 19,5 & 6 & 16,7 \\
\hline Ogólny wypoczynek & 20 & 17 & 12 & 14,6 & 8 & 22,2 \\
\hline Chęć nawiązania nowych znajomości & 18 & 15 & 14 & 17,1 & 4 & 11,1 \\
\hline
\end{tabular}

Źródło: opracowanie własne na podstawie badań ankietowych. 
Określając powód przyjazdu do Kołobrzegu (tab. 4), ankietowani jako najważniejsze czynniki wpływające na ich decyzję podawali położenie w pasie nadmorskim, a także rekomendacje znajomych i rodziny. Zarówno odległość od domu, jak i łatwość dojazdu do miasta nie miały większego znaczenia.

W odpowiedzi na pytanie o oczekiwane korzyści zdrowotne (tab. 5) ankietowani wymieniali przede wszystkim zmianę nawyków żywieniowych, a także poprawę ogólnego stanu zdrowia oraz sprawności fizycznej. Najrzadziej oczekiwali zmniejszenia pojawiających się stanów zapalnych (17\%) oraz poprawy kondycji psychicznej (14\%).

Respondenci zostali również poproszeni o określenie swoich preferencji dotyczących dodatkowych atrakcji, z których chcą skorzystać w Kołobrzegu. Ankietowani

Tabela 3. Zabiegi, z których korzystali kuracjusze podczas pobytu w Kołobrzegu

\begin{tabular}{|c|c|c|c|c|c|c|}
\hline \multirow{2}{*}{ Nazwa zabiegu } & \multicolumn{2}{|c|}{ Ogółem } & \multicolumn{2}{|c|}{ Kobiety } & \multicolumn{2}{|c|}{ Mężczyźni } \\
\hline & os. & $\%$ & os. & $\%$ & os. & $\%$ \\
\hline Masaże & 60 & 51 & 52 & 63,4 & 8 & 22,2 \\
\hline Basen solankowy & 38 & 32 & 26 & 31,7 & 12 & 33,3 \\
\hline Kinezyterapia & 38 & 32 & 27 & 32,9 & 11 & 30,6 \\
\hline Inhalacje & 37 & 31 & 20 & 24,4 & 17 & 47,2 \\
\hline Krioterapia & 37 & 31 & 26 & 31,7 & 11 & 30,6 \\
\hline Laseroterapia & 35 & 30 & 24 & 29,3 & 11 & 30,6 \\
\hline Elektrolecznictwo & 30 & 25 & 17 & 20,7 & 13 & 36,1 \\
\hline Kąpiele solankowe & 29 & 25 & 19 & 23,2 & 10 & 27,8 \\
\hline Zabiegi borowinowe & 24 & 20 & 19 & 23,2 & 5 & 13,9 \\
\hline Basen borowinowy & 18 & 15 & 11 & 13,4 & 7 & 19,4 \\
\hline
\end{tabular}

Źródło: opracowanie własne na podstawie badań ankietowych.

Tabela 4. Główne przyczyny przyjazdu do Kołobrzegu

\begin{tabular}{|l|c|c|c|c|c|c|}
\hline \multirow{2}{*}{ Powód wybrania na pobyt miasta Kołobrzeg } & \multicolumn{2}{c|}{ Ogółem } & \multicolumn{3}{c|}{ Kobiety } & \multicolumn{2}{c|}{ Mężczyźni } \\
\cline { 2 - 7 } & os. & $\%$ & os. & $\%$ & os. & \multicolumn{2}{c|}{$\%$} \\
\hline Położenie nad morzem & 29 & 25 & 20 & 24,4 & 9 & 25,0 \\
\hline Polecenie przez znajomych/rodzinę & 25 & 21 & 21 & 25,6 & 4 & 11,1 \\
\hline Cena pobytu sanatoryjnego & 21 & 18 & 12 & 14,6 & 9 & 25,0 \\
\hline Atrakcyjność turystyczna miejscowości & 18 & 15 & 9 & 11,0 & 9 & 25,0 \\
\hline Możliwość łatwego dojazdu & 13 & 11 & 11 & 13,4 & 2 & 5,6 \\
\hline Odległość od domu & 11 & 9 & 8 & 9,8 & 3 & 8,3 \\
\hline
\end{tabular}

Źródło: opracowanie własne na podstawie badań ankietowych.

Tabela 5. Oczekiwania zdrowotne respondentów wobec pobytu w sanatorium

\begin{tabular}{|l|c|c|c|c|c|c|}
\hline \multirow{2}{*}{ Oczekiwania kuracjuszy } & \multicolumn{2}{c|}{ Ogółem } & \multicolumn{3}{c|}{ Kobiety } & \multicolumn{2}{c|}{ Mężczyźni } \\
\cline { 2 - 7 } & os. & $\%$ & os. & $\%$ & os. & $\%$ \\
\hline Zmiana sposobu odżywiania dostosowana do choroby & 49 & 42 & 33 & 40,2 & 16 & 44,4 \\
\hline Poprawa ogólnego stanu zdrowia & 35 & 30 & 27 & 33,0 & 8 & 22,2 \\
\hline Poprawa krążenia & 31 & 26 & 15 & 18,3 & 16 & 44,4 \\
\hline Poprawa sprawności fizycznej & 28 & 24 & 17 & 20,7 & 11 & 30,6 \\
\hline Poprawa odporności & 26 & 22 & 20 & 24,4 & 6 & 16,7 \\
\hline Złagodzenie bólów & 26 & 22 & 22 & 26,8 & 4 & 1,1 \\
\hline Zmniejszenie pojawiania się stanów zapalnych stawów i kości & 20 & 17 & 15 & 18,3 & 5 & 13,9 \\
\hline Poprawa kondycji psychicznej & 16 & 14 & 11 & 13,4 & 5 & 13,9 \\
\hline
\end{tabular}

Źródło: opracowanie własne na podstawie badań ankietowych. 
najchętniej wybierali spacery $(25,4 \%)$ oraz koncerty $(26,3 \%)$. Najrzadziej wskazywano chęć skorzystania z zabiegów spa \& wellness. Prawdopodobnie spowodowane to jest faktem, że takie usługi są dość kosztowne, ale także dostępne w całej Polsce, nie tylko w tym konkretnym uzdrowisku.

Ankietowani, zapytani o źródło finansowania pobytu w nadmorskim uzdrowisku (tab. 6), wskazali, że wyjazdy te były finansowane $w$ całości ze środków prywatnych $(36 \%)$ lub w ramach świadczeń Narodowego Funduszu Zdrowia (35\%). Tylko osiem osób uczestniczyło w turystyce uzdrowiskowej dzięki refundacji KRUS.

Z informacji na temat zakwaterowania w obiektach turystycznych w Kołobrzegu, w których realizowane są turnusy uzdrowiskowe (tab. 7), wynika, że kuracjusze biorący udział w badaniu najczęściej przebywali w ośrodkach sanatoryjno-wypoczynkowych oraz sanatoriach uzdrowiskowych. Szpital uzdrowiskowy jako miejsce pobytu wskazało 10 respondentów. Spośród ankietowanych kobiet $88 \%$ było zakwaterowanych w sanatoriach uzdrowiskowych.

Ostatnie pytanie dotyczyło oceny zadowolenia kuracjuszy (w skali od 1 - bardzo źle, do 5 - bardzo dobrze) - rys. 1 . W swoich odpowiedziach znacznie wyższe oceny przyznawali mężczyźni. Wyjątkiem jest pytanie o podejście personelu medycznego $(4,03)$, który był przez nich postrzegany gorzej niż przez kobiety.

Opierając się na wynikach przeprowadzonych badań, można zauważyć, że turystyka uzdrowiskowa w Kołobrzegu cieszy się zainteresowaniem głównie

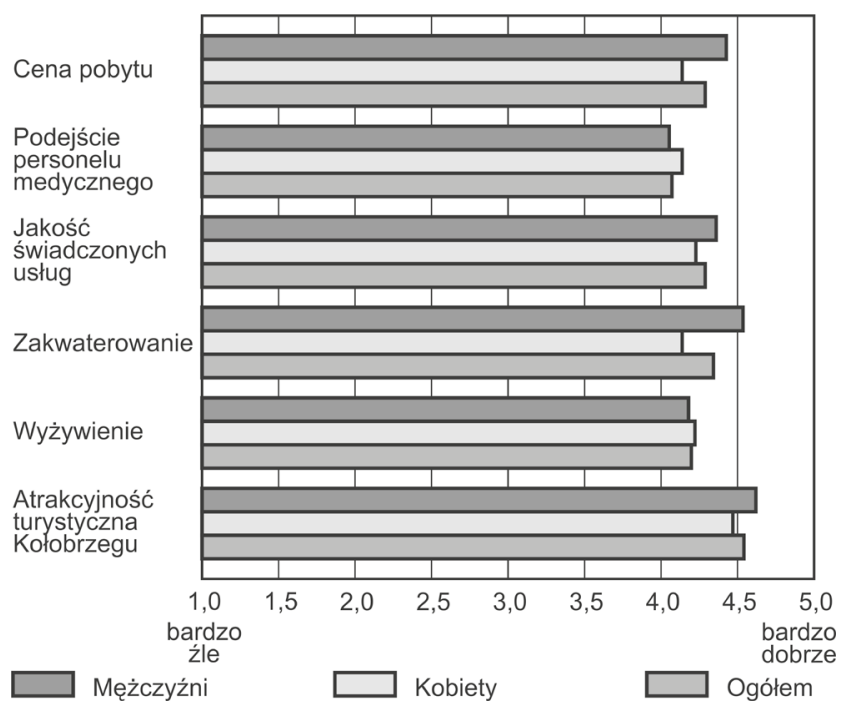

Rysunek 1. Średnia ocena zadowolenia kuracjuszy Źródło: opracowanie własne na podstawie badań ankietowych

wśród osób po 55 roku życia. Kuracjusze ocenili swoje turnusy dobrze, nie tylko pod względem warunków zakwaterowania i czystości w pokojach, ale także ceny za pobyt. Najmniej zadowoleni byli z personelu medycznego, co wynikało z niepełnego dopasowania zabiegów wykonywanych podczas pobytu do typu schorzenia, na które cierpiał dany respondent. Wyniki ankiet świadczą również o tym, że Kołobrzeg ze względu na swoją atrakcyjność turystyczną jest miastem lubianym i chętnie odwiedzanym nie tylko w celach zdrowotnych.

Tabela 6. Źródło finansowania pobytu w Kołobrzegu

\begin{tabular}{|c|c|c|c|c|c|c|}
\hline \multirow{2}{*}{ Źródło finansowania } & \multicolumn{2}{|c|}{ Ogółem } & \multicolumn{2}{|c|}{ Kobiety } & \multicolumn{2}{|c|}{ Mężczyźni } \\
\hline & os. & $\%$ & os. & $\%$ & os. & $\%$ \\
\hline Prywatnie & 43 & 36 & 27 & 32,9 & 16 & 44,4 \\
\hline NFZ & 41 & 35 & 33 & 40,2 & 8 & 22,2 \\
\hline ZUS & 14 & 12 & 12 & 14,6 & 2 & 5,6 \\
\hline PFRON & 10 & 8 & 4 & 4,9 & 6 & 16,7 \\
\hline KRUS & 8 & 7 & 5 & 6,1 & 3 & 8,3 \\
\hline
\end{tabular}

Źródło: opracowanie własne na podstawie badań ankietowych.

Tabela 7. Miejsce zakwaterowania w Kołobrzegu

\begin{tabular}{|l|c|c|c|c|c|c|}
\hline \multirow{2}{*}{\multicolumn{1}{c|}{ Typ ośrodka }} & \multicolumn{2}{c|}{ Ogółem } & \multicolumn{3}{c|}{ Kobiety } & \multicolumn{2}{c|}{ Mężczý́ni } \\
\cline { 2 - 8 } & os. & $\%$ & os. & $\%$ & os. & \multicolumn{2}{c|}{$\%$} \\
\hline Ośrodek sanatoryjno-wypoczynkowy & 47 & 40 & 35 & 42,7 & 12 & 33,3 \\
\hline Sanatorium uzdrowiskowe & 36 & 31 & 20 & 24,4 & 16 & 44,4 \\
\hline Centrum rehabilitacji & 16 & 14 & 13 & 15,9 & 3 & 8,3 \\
\hline Szpital uzdrowiskowy & 10 & 8 & 6 & 7,3 & 4 & 11,1 \\
\hline Hotel z zabiegami spa \& wellness & 8 & 7 & 7 & 8,5 & 1 & 2,8 \\
\hline
\end{tabular}

Źródło: opracowanie własne na podstawie badań ankietowych. 


\section{DYSKUSJA}

Podobne do przedstawionych $\mathrm{w}$ artykule badania uczestników turystyki zdrowotnej, tylko że w skali całej Polski, przeprowadziła kilka lat wcześniej Krzyżanowska (2016). Uzyskane przez nią wyniki dowiodły, że głównymi celami wyjazdów uzdrowiskowych są: chęć poprawy stanu zdrowia, potrzeba leczenia chorób oraz wypoczynku. Za najczęściej występujące schorzenia uznano choroby reumatologiczne, za najrzadsze zaś - przypadłości związane z układem trawiennym i chorobami dróg oddechowych. Najważniejszymi korzyściami dla respondentów okazały się polepszenie samopoczucia i poprawa sprawności fizycznej. Ankietowani, oceniając usługi i elementy związane z pobytami uzdrowiskowymi w Polsce, najlepiej postrzegali jakość oferowanych zabiegów oraz profesjonalne podejście personelu medycznego.

Do zbliżonych wniosków doszli też m.in. Środa-Murawska, Grzelak-Kostulska i Biegańska (2015) oraz Parzych (2015). Z podjętych przez autorki studiów wynika, że usługi sanatoryjne i profesjonalizm obsługi były oceniane przez turystów bardzo wysoko. Z kolei badania przeprowadzone przez Parzycha w Dąbkach (nadmorska wieś Pobrzeża Koszalińskiego o statusie uzdrowiska od 2007 r.) ujawniły, że turyści jako główny cel przyjazdu do miejscowości wskazali przede wszystkim czynności o charakterze uzdrowiskowym: zabiegi pielęgnacyjne, spacery oraz regenerację i wypoczynek.

Przedstawione w artykule wyniki badań wstępnych w pełni korespondują z rezultatami studiów Krzyżanowskiej (2016) i Parzycha (2015). Autorkom niniejszego artykułu udało się jednak zidentyfikować dodatkowe czynniki decydujące o przyjeździe do uzdrowiska Kołobrzeg. Poza wysoko ocenianymi korzyściami z dostępu do naturalnych walorów leczniczych respondenci podkreślali także swe zainteresowanie bazą sportowo-rekreacyjną. Niżej natomiast ocenili usługi prozdrowotne.

\section{PODSUMOWANIE}

W artykule zaprezentowano wyniki eksploracyjnych badań ankietowych, poprzedzających badania właściwe - będą one w najbliższych latach prowadzane wśród kuracjuszy w uzdrowiskach w całej Polsce. Uzyskane dotychczas wyniki dowodza, że Kołobrzeg jest miastem bardzo chętnie wybieranym przez turystów uzdrowiskowych. Większość respondentów odwiedziła je już wcześniej.

Kołobrzeg powszechnie uznawany jest za jedno z najpiękniejszych i największych uzdrowisk w Polsce, które ma bogatą historię i cenne tworzywa lecznicze
- m.in. złoża borowin. Typowe programy lecznictwa i rehabilitacji w ramach turystyki uzdrowiskowej są ustalane indywidualnie i dostosowywane do potrzeb każdego z kuracjuszy. Wyjazdy na turnusy sanatoryjne organizuje się tak, by ośrodek był dopasowany do potrzeb pacjentów pod kątem specjalizacji w leczeniu odczuwanych przez nich dolegliwości.

Rozwój współczesnej turystyki uzdrowiskowej, leczniczej (medycznej), a także spa \& wellness wynika z faktu, że ich uczestnikami są nie tylko kuracjusze z określonymi schorzeniami, ale także osoby bez większych dolegliwości, które chcą prowadzić zdrowy styl życia oraz dbać o swoją sylwetkę, stosując różne zabiegi kosmetyczne i upiększające. Dlatego w wielu obiektach turyści i kuracjusze mają możliwość skorzystania z pobytów sanatoryjnych oraz spa \& wellness. Niewątpliwie poza atrakcyjną ofertą pobytów leczniczych i uzdrowiskowych turystów do Kołobrzegu przyciągają również unikatowe atrakcje turystyczne (m.in. molo, port morski, latarnia morska) oraz odbywające się w okresie letnim liczne wydarzenia kulturalne, festiwale i eventy w plenerze (m.in. na plaży).

Reasumując, dzisiejszy Kołobrzeg należy postrzegać jako prężnie prosperujące uzdrowisko, nie tylko stymulujące rozwój lokalny, ale także wspierające gospodarkę regionu i kraju. To miasto o zróżnicowanych walorach turystycznych (krajoznawczych, wypoczynkowych, uzdrowiskowych) ma dobre zagospodarowanie turystyczne oraz wysoką ocenę atrakcyjności wśród kuracjuszy, co pozwala prognozować dalszy dynamiczny rozwój turystyki uzdrowiskowej. Ważne jest przy tym, by oferta pobytowa odpowiadała ciągle zmieniającym się oczekiwaniom i wymaganiom odwiedzających. Należy więc nieustannie inwestować w rozwój uzdrowiska, unowocześniać infrastrukturę turystyczną i paraturystyczną, aby mogła zaspokajać wszechstronne potrzeby odbiorców.

\section{BIBLIOGRAFIA}

Adamczyk, M.D. (2017). Starzenie się społeczeństwa polskiego wyzwaniem dla zrównoważonego rozwoju. Zeszyty Naukowe Politechniki Śląskiej. Seria: Organizacja i Zarzadzanie, 106, 105108. https://doi.org/10.29119/1641-3466.2017.106.9

Atrakcje w Kołobrzegu (2020). Pobrane z: https://pl.tripadvisor. com/Attractions-g274727-Activities-Kolobrzeg_Western_ Pomerania_Province_Western_Poland.html,2020 (17.04.2020).

Bernat, S., Harasimiuk, M. (2019). Możliwości powstania nowych uzdrowisk na obszarach wiejskich. Kontekst krajowy i regionalny. Analles - Universitatis Mariae Curie-Skłodowska, LXXIV, 93-116. https://doi.org/10.17951/b.2019.74.93-116

Burzyński, T. (red.) (2005). Czynniki wpływajace na jakość i konkurencyjność usług w gminach uzdrowiskowych. Kraków: Instytut Turystyki w Krakowie i SGU RP.

Cieślukowski, Z. (1975). Kołobrzeg. Rys historyczny do II wojny światowej. "Problemy Uzdrowiskowe". Cz. II. Uzdrowisko Kołobrzeg, 4 (92), 135-137. 
Gaworecki, W.W. (2003). Turystyka. Warszawa: Polskie Wydawnictwo Ekonomiczne.

Gillert, O. (1964). Hydrotherapie und Balneotherapie in Theorie und Praxis. Monachium: Pflaum.

Gotowt-Jeziorska, A., Wyrzykowski, J. (red.) (2005). Turystyka a uzdrowiska. Warszawa: Polskie Stowarzyszenie Turystyki.

Hadzik, A., Szromek, A.R., Żylak, D. (2010). Competitiveness of the tourism product of Kołobrzeg spa. Acta Scientiarum Polonorum, Oeconomia, 9 (4), 153-160.

Heider, R., Kierzek, A., Laber, W., Kotuła, J. (2019). A little on the development of Kołobrzeg as a spa - from the past to the present. Otorynolaryngologia, 18 (3/4), 95-97.

Historia uzdrowiska (2020). Pobrane z: https://kolobrzeg.eu/artykul/39/historia-uzdrowiska (12.03.2020).

Januszewska, M. (2015). Perspektywy rozwoju uzdrowisk w Polsce. Zeszyty Naukowe Turystyka i Rekreacja, 1, 116-118.

Jurek, J. (2018). Działalność lecznicza zakładów lecznictwa uzdrowiskowego i stacjonarnych zakładów rehabilitacji leczniczej w 2017 r. Informacja sygnalna. [b.m.]: Urząd Statystyczny w Krakowie, Ośrodek Statystyki Zdrowia i Ochrony Zdrowia.

Kaczmarek, J., Stasiak, A., Włodarczyk, B. (2010). Produkt turystyczny. Pomyst, organizacja, zarzadzanie. Warszawa: PWE.

Kołobrzeg (2020). Pobrane z: https://www.gov.pl/web/zdrowie/ kolobrzeg (1.02.2020).

Kornak, A.S. (1999). Uzdrowiska polskie w systemie rynku i zarządzania marketingowego. Bydgoszcz: Kujawsko-Pomorskie Studium Edukacyjne.

Kornak, A.S., Rapacz, A. (2001). Zarzadzanie turystyka i jej podmiotami w miejscowości i regionie. Wrocław: Akademia Ekonomiczna.

Kroczyński, H. (1969). Polacy w walce o Kołobrzeg 1807. Warszawa: Wydawnictwo Ministerstwa Obrony Narodowej.

Kruczek, Z. (2011). Atrakcje turystyczne. Fenomen, typologia, metody badań. Kraków: Proksenia.

Kruczek, Z. (2012). Atrakcyjność turystyczna uzdrowisk podkarpackich. W: A.R. Szromek (red.), Uzdrowiska i ich funkcja turystyczno-lecznicza (s. 68-70). Kraków: Proksenia.

Krzyżanowska, K. (2016). Turystyka uzdrowiskowa i jej postrzeganie przez kuracjuszy. Turystyka i Rozwój Regionalny, 6, 69-76.

Lecznictwo uzdrowiskowe (2020). Pobrane z: https://www.gov.pl/ web/zdrowie/lecznictwo-uzdrowiskowe (17.01.2020).
Makała, H. (2016). Turystyka uzdrowiskowa w Polsce. Zeszyty Naukowe. Turystyka i Rekreacja, 2, 121-122. https://doi. org/10.5604/01.3001.0010.6966

Małecka, B., Marcinkowski, J.T. (2007). Rys historyczny rozwoju lecznictwa uzdrowiskowego. Czasopismo Naukowe Problemy Higieny i Epidemiologii, 88 (2), 139-142.

Miedziński, M. (2011). Kołobrzeg jako centrum turystyki uzdrowiskowo-wypoczynkowej po 20 latach przemian ustrojowych (1989-2009). W: B. Krakowiak, J. Latosińska (red.), Warsztaty z Geografii Turyzmu. T. 1 (s. 115-126). Łódź: Wydawnictwo Uniwersytetu Łódzkiego. https://doi. org/10.18778/7525-586-7.09

Przyroda Kołobrzegu i okolic (2020). Pobrane z: http://www.przyroda.powiat.kolobrzeg.pl (17.01.2020).

Sanatoria.org (2020). Pobrane z: http://www.sanatoria.org (1.02.2020).

Szromek, A.R. (2013). Cechy atrakcyjności polskich uzdrowisk. Zeszyty Naukowe Politechniki Ślaskiej, Seria: Organizacja i Zarzadzanie, 64, 251-264.

Środa-Murawska, S., Grzelak-Kostulska, E., Biegańska J. (2015). Jakość usług oferowanych przez uzdrowisko Ciechocinek w opinii kuracjuszy. Zeszyty Naukowe Uniwersytetu Szczecińskiego. Ekonomiczne Problemy Turystyki, 2 (30/853), 109-123. https:// doi.org/10.18276/ept.2015.2.30-07

Trzeciak,B.(1997).Leczenieuzdrowiskowe.W:W.Rewerski,W.S.Gumułka. Encyklopedia zdrowia PWN. T. 1 (s. 512). Wydanie V. Kraków: Wydawnictwo Naukowe PWN.

Urząd Miasta Kołobrzeg (2020). Pobrane z: http://www.kolobrzeg.pl (2.06.2020).

Ustawa z dnia 28 lipca 2005 r. o lecznictwie uzdrowiskowym, uzdrowiskach i obszarach ochrony uzdrowiskowej oraz o gminach uzdrowiskowych. Dz.U. 2005, nr 167, poz. 1399.

Uzdrowiska (2020). Pobrane z: https://www.sanatoria.com.pl/ a,422,uzdrowiska.html (15.03.2020).

Wolski, J. (1970). Turystyka zdrowotna a uzdrowiska europejskich krajów socjalistycznych. Warszawa: Polskie Towarzystwo Balneologii, Bioklimatologii i Medycyny Fizykalnej.

Wykaz uzdrowisk wraz z kierunkami leczniczymi (2020). Pobrane z: https://www.gov.pl/web/zdrowie/wykaz-uzdrowisk-wraz-z-kierunkami-leczniczymi (14.03.2020). 